\title{
SOCIAL PEDAGOGICAL ASSISTANCE FOR STUDENTS WHO EXPERIENCE BULLYING SITUATIONS AT SCHOOL
}

\author{
Ilona Klanienè \\ Klaipeda University, Lithuania \\ Asta Bražinskienè-Gružauskė \\ Klaipeda „Aitvaro“ Gymnasium, Lithuania
}

\begin{abstract}
The frequency of bullying and the consequences for the child's development encourage targeted social pedagogical assistance in Lithuanian schools. The article reveals the opportunities of social pedagogical assistance at school for students who have experienced bullying by peers. The results of the qualitative research (partially structured interviews with school leaders, social pedagogues, and class teachers) are presented. The analysis of the research results has revealed that the following social pedagogical support measures are applied at school: the provision of emotional support, consultations, social skills classes, work with parents, individual conversations and etc.. The main difficulties identified by the informants in assisting students are the lack of parental cooperation, the passivity of teachers and a lack of staff competencies to deal with bullying situations. By increasing the possibilities of social pedagogical assistance at school, the informants offer to increase parental responsibility, improve pedagogues ' competencies, cooperate with assistance organisations.
\end{abstract}

Keywords: class teachers, school, school leaders, social pedagogical assistance, students who experience bullying situations, social pedagogues.

\section{Introduction}

Recommendations for the prevention of school violence, which emphasize the school's responsibility for dealing with the bullying situation, was nationally approved In Lithuania in 2017. The responsibility of a school for the safety of children is also emphasized in other strategic documents (Lietuvos Respublikos švietimo įstatymas, 2011).

Therefore, the issue of student safety is a priority in order to ensure the successful education and socialization of a child. The issue of social and psychological safety of students is closely linked to bullying among peers. Although applied researches are being performed, as well as programs are being carried out in Lithuania, bullying still remains one of the most relevant problems for many students (Grigaliūnienè, Kontrimienè et al., 2012, Lukoševičiūtè, Šmigelskas, 2019). Constant experience in bullying situations causes not only 
short-term, but also long-term consequences for students (Targamadze, Valeckiene, et al. 2007, Olweus, 2011;).

Such children experience a feeling of insecurity, anxiety, and sometimes they face with suicidal thoughts, especially in long-lasting cases of bullying (Chester, Callaghan et al. 2015). Such children must be provided with social pedagogical assistance at school, as required by the Convention on the Rights of the Child (1989) and national documents (Lietuvos Respublikos švietimo įstatymas, 2011, LR Švietimo ir Mokslo ministro įsakymas „Dèl Socialinès pedagoginès pagalbos teikimo vaikui ir mokiniui tvarkos aprašo patvirtinimo“, 2016). Although the above mentioned documents regulate the provision of assistance, and define the roles of assistance specialists, there is a lack of those specialists at schools, teachers and other staff lack knowledge on how to recognize this problem (Gaudiešiūtè, Kavaliauskaitè, 2020).

Researches on the phenomenon of bullying are being actively carried out both in Lithuania and worldwide. The frequency of bullying at schools (Olweus, 2011; Robichaud, 2007), forms of bullying (Olweus, Limber; 2018,), consequences of bullying (Robichaud, 2007) are being researched. Much attention is paid to the analysis of cyberbullying (Gedutiené, Šimulionienè, et al., 2012). Researchers are interested in parental involvement in bullying prevention (Mavroudis, Bournelli, 2016). Although scientific researches have answered many questions regarding bullying, there is still an intense search for ways to reduce bullying at schools (Olweus, Limber; 2018), and there is a particular lack of researches which could scientifically justify the opportunities for social pedagogical assistance to a child who has experienced bullying at school. Social pedagogical assistance is being mainly researched without distinguishing the problem of bullying in general (Merfeldaitè, 2007, Trakšelys, Martišauskienè, 2016, Brake, Kelly, 2019). As G. Kvieskienè (2015) notes, non-decrease in bullying cases and the ratio of specialists, which is significantly lower than school demands, raise concerns about the provision of assistance, and encourages researchers to delve into these issues. Thus, referring to the relevance of the problem, the following questions are being raised in the article: who and how provides assistance at school for students who have experienced bullying, what difficulties school administration, class teachers, assistance specialists face in providing it, what opportunities to provide such assistance at school are. The object of the article is social pedagogical assistance for students who experience bullying situations at school. The aim of the article is to reveal the opportunities of social pedagogical assistance for students who have experienced bullying situations at school. 
SOCIETY. INTEGRATION. EDUCATION

Proceedings of the International Scientific Conference. Volume III, May $28^{\text {th }}-29^{\text {th }}$, 2021. 292-304

\section{Review of the Literature}

All of the above-mentioned documents emphasize that each pupil must receive help at school. The analysis of social pedagogical support in the article is based on Olweus's definition of bullying, which describes it as "a conscious, repetitive negative actions to offend, hurt, or cause discomfort to another person" (Olweus, 2011). Researchers who are analysing bullying situations (Olweus, 2011; Craig et al. 2007; Girdvainis. 2013) distinguish between direct and indirect bullying. Direct bullying is defined by researchers as direct actions towards a bullied child, such as beating, nicknaming, etc. Indirect bullying is defined as hurting a child without taking direct aggressive actions, for example, by spreading rumors, social isolation, etc. (Craig et al., 2007; Mavroudis, Bournelli, 2016). Bullying among peers is caused by both environmental and individual factors (Olweus, Limber, 2018). The researchers who have studied these causes assume that bullying can be influenced by certain attributes such as a child's social status, nationality, race, appearance, disability, etc.. (Targamadzè, Valeckienė, 2007; Girdvainis, 2013). As noted by S.J. Milton (2010), children who do not have distinctive traits also experience bullying. A distinctive feature is not a reason to be bullied, but it can attract the attention of bullies who have a tendency to intentionally hurt others (Klanienè, Rupšienè et al., 2014). One of the common causes of bullying is a child's social poor social skills, as it makes it difficult for a child to establish himself in a peer group (Lukoševičiūtè, Šmigelskas, 2019). Researchers unambigiously claim that bullying has consequences for child's physical, psychological and social health. First of all, children who experience bullying suffer from fear and insecurity, which reduces the already low selfesteem, increase distrust of other people (Grigaliūnienè, Kontrimienè et al., 2012). The research of I.Vareikiene (2011) reveals that children who are physically or psychologically weaker than a bully or his group, are very likely to become the targets of bullying (Robichaud, 2007).

One of the most effective programs directed towards helping students reduce bullying at school is the world-renowned Olweus bullying prevention program. This program provides essential preventive measures at 3 levels: school, group, individual (Olweus, 2018). At the school level, the following measures have been identified: assessment of bullying incidence, organisation of trainings, breaktime supervision of teachers, anticipation of bullying outcomes, monitoring child's behavior, work with parents, etc .; at group level (conducting class lessons, work with students' parents, etc..); at the individual level (intervention of school staff in bullying, individual interviews with a victim and a bully, their parents, effective monitoring, response until a bullying situation ends).

First of all, it is very significant to provide help at an individual level (Targamadzè, Valeckienè, 2007, Mavroudis, Bournelli, 2016). An individual 
conversation with a bullied child and his parents is important here, as it helps to express feelings, to gather information about the case, and make a plan on how to protect a child from repeated bullying. Most researchers (Olweus, Limber, 2018) refer to a conversation as the main tool, as it is usually conducted by an experienced professional. Of course, at an individual level, not only the help of assistance specialists (social pedagogue, psychologist, etc.) but also of class teachers as well as subject teachers is extremely important (Indrašienè, Suboč, 2008). Another area of social pedagogical assistance is work in a group. It is important for a child to have support not only from adults but also from peers. At the group level, a class teacher has a special role, as she can create an emotionally safe microclimate in the classroom, notice changes in child's behavior, organize classroom lessons, and improve social skills (Olweus, 2011).

Social pedagogical assistance for children being bullied by peers requires the establishment of ground rules for behaviour preventing bullying, the consequences for misbehavior, and the implementation of assistance system (Brake, Kelly, 2019). Researchers have proved that the active involvement of assistance professionals and administration in the process of social pedagogical assistance significantly improves problem solving (Indrašienè, Suboč, 2008; Kvieskienè, 2015). While solving the problem of bullying, it is significant to everyone at school to know theirs roles, commitments and the limits of responsibility. In summary, the assistance system for a child being bullied at school needs to be developed and implemented. An example of such systematic assistance is the Olweus Bullying Prevention Program, which offers effective measures at school, group and individual levels. At an individual level, assistance is provided by assistance specialists, at group level - by class teacher, and at the school level by school administration and all staff members.

\section{Research Methodology}

Bullying is one of the more sensitive topics for students, so the methodology of the qualitative research was chosen, and individual interviews with students who experienced bullying and their parents were scheduled. Schoolmasters were approached, but they claimed that bullying is a painful experience, therefore, it is no use for students and their parents to recall this incident again. This way, it was decided to limit the interviews to assistance providers only. Representatives of school administration (schoolmasters and deputies for education), class teachers, social pedagogues were chosen as informants. These intended groups represented all levels of assistance at school: institutional (administration representatives), groups (class teachers), individual (social pedagogues).

In order to reveal social pedagogical assistance opportunities at school for children experiencing bullying from peers, a semi-structured interview was 
chosen. Referring to the analysis of the scientific literature, the interview topics were distinguished, and in case of uncertainty, the informants were asked additional questions. The following topics were singled out for class teachers and social pedagogues: characteristics of children being bullied by peers; methods of providing assistance, difficulties encountered, evaluation of assistance, suggestions for the improvement of social pedagogical assistance. In addition to the topics already mentioned, the school administration was additionally asked questions on the topics of organizing social pedagogical assistance at school.

The survey sample. A criterion-based selection method was used while selecting the informants. The essential criterion was at least 3 years of experience in providing assistance to bullied students. 5 progymnasiums and one gymnasium, 6 representatives of school administration, 6 class teachers and 6 school social pedagogues participated in the research. Interviews with the class teachers were conducted at schools where the informants work. The time was agreed in advance, the consents of study participants for participation in the interview were obtained. Four class teachers,, who had been faced with bullying cases were recommended by social pedagogues and two - by school administration. Interviews with the social pedagogues and school administration also took place in educational institution. The answers of the informants were coded: the answers of class leaders were coded by K1, K2, K3, K4, K5, K6; of social pedagogues by SP1, SP2, SP3, SP4, SP5, SP6. The statements of school administration are coded A1, A2, A3, A4, A5, A6.

The results of the research were analyzed using the content analysis method. The obtained data were analyzed in stages: by means of repeated reading of answers, it was searched for semantically similar answers and "keywords", then, categories and subcategories were constructed, and later interpretations of the separated categories and subcategories were made (Bitinas, Rupšienė, Žydžiunaite, 2008). After processing the research data, a research report, which had been coordinated with the study participants, was prepared. The research was conducted referring to the requirements of research ethics.

\section{Research Results and Their Discussion}

In order to assess the situation of social assistance at school, firstly, it was important to find out which groups of children most often experience bullying at school. The informants were asked a question "How would you describe a child who is being bullied by schoolmates at school?". Referring to the interpretation of the research data, 8 subcategories were distinguished in the category "Groups of children most often experiencing bullying”. While describing children who experience bullying, almost all informants distinguished an essential feature - low 
self-esteem. Informants note that a child who experiences bullying from peers is "closed" (K4, SP2), "shy” (K4, K5, SP3); "shrunken, timid, avoids his peers, disadvantaged, a victim" (A1). Another group of students experience bullying from peers due to the external features. Most often children suffer from peer bullying due to overweight, non-standard appearance and clothing. Most often, such children have "bulgy ears, different shape of noses" (SP6), "exceptional hair color or overweight problems" (A4). Others experience bullying because of personal qualities, different attitude: "they stand out with some kind of thinking, different thinking, have different attitude, they like other things" (A2). Learning achievements can also lead to bullying. Both gifted and incompetent students experience peer bullying. As the results of the research has revealed (Milton, 2010; Girdvainis, 2013), students may experience bullying due to the lack of social competence. The informants state that children who lack "communicative skills to make friends“(K5), as well as „efective communication skills among peers"(SP1, SP5) are more likely to experience bullying. Class teachers, social pedagogues see the risk of children with special educational needs to be bullied: "they have behavioral or other health disorders" (K6); "often there are students with special educational needs" (SP2). Students with unhealthy behaviour also experience bullying: "who are prone to aggression" (K1); "they may sometimes say uncensored words and insult in defense or in order to befriend with their peers" (K5); „the level of impulsivity is too high” (SP4). The research also found out that students are more likely to experience bullying from peers because of their social status: "in economically deprived families, which may face with deprivation, the social status is not at a very high level" (K5); "children from socially neglected families, living in more difficult conditions" (A3).

Most often, assitance for students who experience bullying is provided by assistance specialists at school: "first of all, I adress social pedagogue"(K6); "usually a psychologist helps" (SP5). Class teachers also provide classroom support to students at school: „a class teacher is the one with whom this work is usually done" (SP6). Social pedagogues and school administration emphasize the role of the child welfare commission in the assistance process: "and we deal with this together in the child welfare commission" (SP5). School administration and class teachers emphasize that the whole school community participates in the process: "the whole school environment helps, including social pedagogue, psychologist, school administration and colleagues "(K4); "Formally, it is the responsibility of coordinator of the program, but in fact, everyone at school is responsible" (A3). Thus, the responsibility for providing assistance at school should be accepted by the whole school community, by the most frequently mentioned providers of assistance - class teachers, assistance professionals, and by the child welfare commission. 
Olweus \& Limber, (2018) point out that assistance for students experiencing bullying can only be effective if it is provided at school, classroom and individual levels, therefore during the interview, a question was asked: "How do you provide social pedagogical assistance to children who experience bullying at school?" In the category "Methods of social pedagogical assistance to students who have experienced bullying”, 6 subcategories have been distinguished: individual conversations, provision of emotional support, monitoring, development of social skills in a group, mobilization of other specialists, educational activities. Class teachers and social pedagogues (K1, K2, K3, K4, K5, K6, SP2, SP3, SP5, SP6) stated that social pedagogical assistance is provided to children who were bullied by peers by talking to them and their parents individually: "conversations"(K1, SP3); "I talk to a bullied child, I talk to his parents" (SP5).

Another direction of assistance being distinguished - provision of emotional support: "firstly, I hug, comfort them (K2)," I assure the child that he is not alone, and that it is not his fault "(SP4); "I always encourage, let them call me, and they can turn to me if something happens"(K6). Regarding provision of assistance, class teachers emphasised a need not only to provide individual assistance, but also to learn to communicate in a group: “ it is very hard to him, as in a team he will need to work and learn, sometimes even to get over himself" (K5); Such assistance is provided by social pedagogues, while conducting social skills classes during which students improve their social skills, as illustrated by the following statement: "social skills development sessions, how to communicate, how to develop communication skills, how to get to know yourself, how to make decisions, how to solve problems, are being organised "(SP2).

Another area of assistance emphasised by the informants is the implementation of preventive activities. Class teachers carry out activities on bullying prevention during class hours by organizing discussions, role-plays, watching films, etc. Social pedagogues are more involved in educational activities: "I teach and educate" (SP2), "carry out researches, conduct researches to find out the impact of the whole environment on the student, what difficulties he faces"(SP1). Bullying prevention is also organized at the school level: „organization of preventive activities, development of programs, organization of projects, competitions"(SP2). Both class teachers and social pedagogues emphasised the long-term observation of well-being of a child who has experienced bullying, as a necessary measure. The informants (K6, SP5, SP3) noted: "even if bullying is not felt anymore, I still observe and keep asking how that person feels?" (SP3). Class teachers and social educators also work with both school specialists and other organizations to provide assistance. The informants (K3, K4, K5, SP5, SP6) noted that, if necessary, they seek help from child welfare 
commission, other specialists, institutions "in extreme cases, if we are not able solve at school, we turn to other institutions, - such as SCRP, police "(SP5).

Informants were additionally asked to evaluate the effectiveness of social pedagogical assistance to children who have experienced bullying. Individual conversations were emphasised as the most effective tool: "these are individual conversations with children, which sometimes are enough" (SP2). However, group discussions were described by both class teachers and social pedagogues as completely ineffective tools. Another measure identified by informants as being effective is emotional support: "emotional support" (SP2). One more effective tool of pedagogical assistance is to provide practical examples of behavior in a bullying situation: "some examples of what to do if you are being bullied" (K1). The informants see the effectiveness of social pedagogical assistance in group activities, where joint activities with classmates are organized. The informants also stated that the effectiveness of the assistance is ensured by the Olweus bullying prevention program, implemented at the school level: "all these principles are effective under the Olweus program" (SP1). Lectures were mentioned as the most ineffective tool in dealing with bullying cases. All informants noted that the provision of effective support to a child is primarily disturbed by the indifferent attitude of school staff towards bullying, inability to delve into the child's situation, when you reject child's approach: ,if I say: - I do not have time, come tomorrow "(K5); social pedagogues emphasize the personal responsibility of a teacher, "ineffective help means doing nothing if child approaches you" slip through the fingers "(SP4).

Most of the authors who have studied bullying cases (Klanienè, Rupšienè et al., 2014; Mavroudis, Bournelli, 2016) point out that the involvement of all school staff and support from school administration in solving bullying situations are extremely significant. In order to find out how assistance is provided at school for children being bullied by their peers, the representatives of administration were asked an additional question "How is assistance organized?" In the category "Organization of support", 5 subcategories were distinguished: development of an information system, implementation of measures under the Olweus program, individual assistance, specialists and cooperation, feedback. Firstly, all the informants noted that a bullying reporting system has been created. The support system is being developed through the implementation of social and emotional education programs. Olweus bullying prevention program was the most frequently mentioned by the informants: "yes, this is the Olweus program that is designed and traces how to recognize, how to monitor, how to capture, and what to do next." (A3). The representatives of school administration indicated the essential steps of the implementation of this program, which they apply in their schools: 1) bullying prevention; 2) an interview with a bullied student; 3) clarification of bullying situation; 4) informing parents; 5) direction to 
assistance. All the informants mentioned that the most important thing is to direct a child to individual assistance: "then we look again what kind of support he may need. Maybe a psychologist, maybe a social pedagogue is needed; what parents need" (A3).

Disciplinary measures for bullies are also anticipated in the assistance system. "There is punishment ladder, and children know that there will be a conversation for the first time. After that, they will face with consideration, and the final measure is a proposal to change school"(A4). Another important element in the assistance system is adoption of common agreements and compliance with them: "there is a system, and class teacher primarily approaches social pedagogue, later me"(A4). Moreover, agreements are significant in defining the role of each school staff's member in the assistance system, which is first provided by subject teacher. "If a teacher is already failing, he informs parents, then turns to a class teacher and, then, if a problem cannot be solved - to specialists" (A5). While providing assistance, it is very important to anticipate feedback regarding the effectiveness of assistance: "we really try to notice, are constantly observing both sides" (A4). Other informants note that there is a need to observe a bullied child more often, as they feel that a buly sometimes receives more attention while anticipating the consequences and taking disciplinary action than a child who has been bullied: „, there is often a tendency to focus more on an offender than on a victim, who has been bullied, as much work is done with a bully" (A3).

While analyzing the possibilities of social pedagogical assistance for students who have experienced bullying, the opinions of the informants on the difficulties encountered while providing assistance were important. In the category "Difficulties encountered while providing social pedagogical assistance to a student who has experienced bullying" the following subcategories were distinguished: misbehavior of students from families at social risk, insufficient involvement of parents in cooperation, difficulty in approaching a student who has experienced bullying, lack of practical assistance measures, indifference of teachers to bullying situations. The informants stated that the biggest challenge rises in the misbehavior of children from families at social risk: "they bring this model, which they have in their family, to school. If a child sees parental fighting, and thinks that such a model exists, it is very difficult to explain him that this is not the case "(A4). Another challenge in providing assistance to children who have experienced bullying is the disturbances associated with parental cooperation. Here, the informants emphasised 2 categories of parents who are indifferent to their child's problems. The first category inludes parents of a bullied child: "we cannot send a child to a psychologist in town, but only to recommend, however, if parents do not want to, we are not able to do anything" (A3); another group of parents who raise challenges inludes parents whose children bully other 
children: "parents think it is school's responsibility and are not involved in the mutual work" (A4). Some class teachers and social pedagogues experience difficulty in approaching a child who has experienced bullying: "if a child is difficult to talk to, and if he does not speak or tells a lie that everything is okey" (K3); "it is difficult to talk to that child" (SP3). Class teachers lack practical tools, their systematization: "you need to read, analyze, structure that material, you need particular tools, situations" (K5). Social pedagogues notice indifference of teachers to bullying situations: "cases when the teachers who work at school state they are reacting, while, in fact, you know they are lying or are pretending not to see those situatations" (SP1).

During the interviews, the informants provided suggestions for the improvement of social pedagogical support for the students who have experienced bullying. Referring to the interpretation of the research data, 7 subcategories were distinguished in the category "The suggestions of the informants for the improvement of social pedagogical assistance“: community education, working with parents to increase parental responsibility, development of communication skills of students, restrictions on the viewing of certain television programs, strengthening teamwork, qualitative implementation of the Olweus bullying prevention program, school staff response to bullying situations

As the data in the above figure show, the informants identified areas for improvement that are important in helping students who have experienced bullying. Most of them involve not only the school level but also the involvement of other institutions. First of all, it is necessary to educate a community, by organizing trainings for teachers, parents and the general public. Moreover, the participants of the research also mentioned that higher parental responsibility would increase the effectiveness of assistance: "I miss higher level of parental responsibility, so that bullies would be punished for not fulfilling their responsibilities" (A4). Class teachers emphasize the responsibility of parents to provide assistance to their children: "psychological assistance must be necassiraly provided, however, currently it is provided only with the consent of parents" (K4). It is also suggested to restrict TV programs that encourage bullying.

The representatives of administration miss greater cooperation and initiative from other assistance organizations: "services that provide assistance toa child should be more involved in these activities and perhaps initiate some kind of assistance to the school itself. It coul be the same pedagogical psychological service, police, as well as family centers"(A3). At the school level, it is offered to carry out the Olweus program in a qualitative way because "it has all the components in it. We all know what, where, how and when to do, it would be really helpful for those children" (SP3). In addition, social pedagogues miss teamwork: „the unity of teachers, class teahers, a vision of a common goal. I would like 
everyone to work in one direction in helping a child" (SP5). Class teachers believe that it is important to improve students' communication skills: "children could not only gain academic knowledge, but also have a communication training course at school (K5). All the informants noted that the most important thing for the whole school community is to respond to bullying: „not to be indifferent, and then the whole problem is solved faster. Everyone knows their functions, only they need to be performed. "(A2).

To sum up, it can be stated that social pedagogical assistance, offered by the research participants to students who have experienced bullying measures, are related to the improvement of educational work in society, greater parental involvement in bullying prevention, improvement of students' social skills, restriction of television programs. At the school level the implementation of the Olweus program, the strengthening of teamwork and a competent response to bullying situations would be most helpful.

\section{Conclusions}

The analysis of the interview data revealed that the greatest risk of experiencing bullying at school is among students who differ significantly from others in appearance, character traits, attitudes and learning achievements. In addition, a students' lack of social skills, social status of parents and developmental disorders can be factors determining students' bullying experience. A case of bullying experienced by students shows that students need various levels of assistance: school, group, individual.

The most effective social pedagogical support for children experiencing peer bullying was emphasised at the individual level (individual conversations, emotional support, monitoring student's situations). According to the informants, group activities are effective only if conditions are created for joint activities with classmates, and during which social skills are developed. At the school level informants give priority to Olweus's bullying prevention program because it offers effective, practically proven assistance measures. The assistance system works well if all school staff follow common agreements and take appropriate action, provide feedback, cooperate with professionals and other organizations. The informants pointed out that more attention is paid to the search for means to sanction a bully than to help a victim. One of the essential conditions for the provision of effective assistance is teacher's willingness to respond to bullying situations, as well as allocation of additional time for help.

The members of school community treat assistance to a student who has experienced bullying differently. While evaluating the provision of assistance, school's administration places more emphasis on the implementation of bullying prevention at school level, and distinguishes the following performance 
indicators, such as reduction of bullying, cooperation of specialists and responsibility as efficiency indicators. While evaluating assistance, social pedagogues and class teachers emphasise individual and group levels of assistance, they offer to put more attention to well-being and changes of a child who has experienced bullying. Most of the measures offered by the informants, which would improve assistance, require not only the involvement and responsibility of school but also of other institutions and society. At school the competent response of school staff to bullying, parental responsibility and active involvement in assistance, a qualitative implementation of the Olweus program and the improvement of teamwork would best improve assistance. Thus, school has all opportunities to provide timely assistance for students who have experienced bullying by including all school community, by improving teamwork and by cooperating with assistance organisations.

\section{References}

Bitinas, B., Rupšienė, L., Žydžiunaitè, V. (2008). Kokybiniu tyrimu metodologija. Klaipèda: S. Jokužio leidykla.

Brake, A., Kelly, S. (2019). Camaraderie, Collaboration, and Capacity Building:A Qualitative Examination of School Social Workers in a Year Long Professional Learning Community. The Qualitative report, 24(4), 667-692.

Chester, K.L., Callaghan, M., Cosma, A., Donnelly, P., Craig, W., Walsh, S., Molcho, M. (2015). Cross-national time trends in bullying victimization in 33 countries among children aged 11, 13 and 15 from 2002 to 2010. Eur J Public Health, 25(2), 61-64.

Craig, W., Pepler, D., Blais, J. (2007). Responding to Bullying: What Works? School Psychology International, 28 (4), 1-14.

Gaudiešiūtè, E., Kavaliauskaite, D. (2020). Vaiku ir paaugliu psichikos sunkumai ir pagalbos galimybès mokyklose. Lietuvos situacijos analizé. Retrieved from http://kurklt.lt/wpcontent/uploads/2020/03/Esamos-situacijos-analiz\%C4\%97.pdf

Gedutienè, R., Šimulionienè, R., Čepienè, R., et al. (2012). Patyčios elektroninèje erdvejje: jaunesniojo amžiaus paauglių patirtis. Tiltai, 1, $133-148$.

Girdvainis, G. (2013). Patyčios tarp mokinių bendrojo lavinimo mokykloje: samprata, dalyviai, priežastys ir padariniai. Jaunuju mokslininku darbai, 2 (40), 8-13.

Grigaliūnienè, V, Kontrimienė, A.,Račkauskienė, A. ir kt. (2012). Patyčių psichosocialiniai ir ekonominiai aspektai Kauno bendrojo lavinimo mokyklose. Sveikatos mokslai, 3 (22), 68-71.

Indrašienè, V., Suboč, V. (2008). Tėvų požiūris ị socialinès pedagoginès pagalbos mokykloje organizavimą. Socialinis ugdymas, 5 (16), 59-72.

Klanienè, I., Rupšienè, L., Šmitienè, G., Baraldnes, D. (2014). Mokiniu lygios galimybès ir ribojimai bendrojo ugdymo mokykloje. Monografija. Klaipėda: Ku leidykla.

Kvieskienè, G. (2015). Sumanioji edukacija - socialinėms industrijoms. Socialinis ugdymas, 41(2), 5-16.

Lithuanian Progress Strategy. "Lithuania 2030”. (n.d.). Retrieved from https://lrv.lt/ uploads/main/documents/files/EN_version/Useful_information/lithuania2030.pdf 
Proceedings of the International Scientific Conference. Volume III, May $28^{\text {th }}-29^{\text {th }}$, 2021. 292-304

LR švietimo istatymas $2011 \mathrm{~m}$. kovo 17 d. Nr. XI-1281. (2011). Retrieved from https://eseimas.lrs.lt/portal/legalAct/lt/TAD/TAIS.395105/asr

LR Švietimo ir mokslo ministro isakymas „Dèl smurto prevencijos igyvendinimo mokyklose rekomendaciju patvirtinimo". (2017). Retrieved from https://e-seimas.lrs.lt/ portal/legalAct/lt/TAD/2dc533c0100c11e7b6c9f69dc4ecf19f

LR Švietimo ir mokslo ministro isakymas „Dèl Socialinès pedagoginès pagalbos teikimo vaikuiir mokiniui tvarkos aprašo patvirtinimo“. (2016). Retrieved from https://eseimas.lrs.lt/portal/legalAct/lt/TAD/06ad87e0a20911e68987e8320e9a5185

Lukoševičiūtė, J., Šmigelskas, K. (2019). Lietuvos moksleiviu pasitenkinimas gyvenimu: HBSC tyrimo rezultatai. Sveikatos mokslai, 29(4), 48-52. DOI: 10.35988/sm-hs.2019.056

Mavroudis, N., Bournelli P. (2016). The role of drama in education in counteracting bullying in schools. Cogent Education, 3, 1-12.

Merfeldaite, O. (2007). Socialinès pedagoginès pagalbos efektyvumas mokykloje: klasių auklètojų požiūris. Socialinis ugdymas, 3 (14), 8-18.

Milton, S.J. (2010). Student's expierences of aggressive behaviuor and bully problems in Irish schools. Irish Educational Studies, 29 (2), 131 - 152.

Olweus, D. (2011). Patyčios mokykloje. Ka žinome ir ka galime padaryti. Vilnius: Alma Littera.

Olweus, D., Limber, S.P., Flerx, V. C., Mullin, N., Riese, J., Snyder, M., Thyholdt, R., Baraldsnes, A. (2018). Olweus Patyčiu prevencijos programa. Igyvendinimo mokykloje vadovas. Kaunas: Vitae Litera.

Robichaud, M. G. R. (2007). Vaikas kenčia pažeminimus mokykloje. Vilnius: Baltos lankos.

Targamadzè, V., Valeckienè D., (2007). Patyčiu bendrojo lavinimo mokyklose samprata: priežasčių, formų ir pasekmių diskursas. Acta Pedagogika Vilnensia, 19, 159-171.

Trakšelys, K., Martišauskienè, D. (2016). Švietimo paslaugų kokybė: efektyvumas, rezultatyvumas, prieinamumas. Tiltai, 1 (73), 191-205.

Vareikienè, I. (2011). Mokiniu patyčios ir jų prevencijos galimybès Kauno miesto mokykloje. Daktaro disertacija. Kaunas: LSMU. 